Article

\title{
Short-Term Root-Zone Temperature Treatment Enhanced the Accumulation of Secondary Metabolites of Hydroponic Coriander (Coriandrum sativum L.) Grown in a Plant Factory
}

\author{
Duyen T. P. Nguyen ${ }^{1}$, Na Lu ${ }^{2, *}$, Natsuko Kagawa ${ }^{1,2,3, * \mathbb{D}}$, Mizuki Kitayama ${ }^{1}$ and \\ Michiko Takagaki ${ }^{1}$ \\ 1 Graduate School of Horticulture, Chiba University, 648 Matsudo, Chiba 271-8510, Japan; \\ duyentuu0406@gmail.com (D.T.P.N.); Mizuki.Kitayama@gmail.com (M.K.); mtgaki@faculty.chiba-u.jp (M.T.) \\ 2 Center for Environment, Health and Field Sciences, Chiba University, 6-2-1 Kashiwanoha, Kashiwa, \\ Chiba 277-0882, Japan \\ 3 Plant Molecular Science Center, Chiba University, 6-2-1 Kashiwanoha, Kashiwa, Chiba 277-0882, Japan \\ * Correspondence: na.lu@chiba-u.jp (N.L.); knatsuko@faculty.chiba-u.jp (N.K.)
}

Received: 12 February 2020; Accepted: 17 March 2020; Published: 19 March 2020

\begin{abstract}
The demand for high-nutrient and fresh vegetables, including coriander, has been growing rapidly. A plant factory with artificial lighting enables the application or suppression of stress conditions to plants for producing high-quality vegetables. This study aimed to determine a suitable root-zone temperature (RZT) treatment for enhancing the biomass and secondary metabolite content of hydroponic coriander plants. The combination of a mid-RZT $\left(25^{\circ} \mathrm{C}\right)$ pre-treatment with low $\left(15^{\circ} \mathrm{C}\right.$ or $20^{\circ} \mathrm{C}$ ) or high $\left(30^{\circ} \mathrm{C}\right.$ or $35^{\circ} \mathrm{C}$ ) RZT for a short period ( 3 or 6 days) was applied to the plants before harvesting. The fresh weights of the coriander plants were reduced under RZT stress. By contrast, the content of secondary metabolites, including ascorbic acid, carotenoids, phenolic compounds, chlorogenic acid, and the antioxidant capacity of the plants were enhanced by the combination of the lowest or highest RZT $\left(15^{\circ} \mathrm{C}\right.$ or $\left.35^{\circ} \mathrm{C}\right)$ and the longer stress period (6 days). Growing coriander under an RZT of $30^{\circ} \mathrm{C}$ for 6 days can produce large amounts of bioactive compounds and water, whereas growing coriander at an RZT of $15^{\circ} \mathrm{C}$ for 6 days can produce high dry biomass and secondary metabolite content.
\end{abstract}

Keywords: antioxidant capacity; chlorogenic acid; Coriandrum sativum L.; indoor cultivation; rutin; short-term stress

\section{Introduction}

Coriander (Coriandrum sativum L.) is an annual herbaceous plant, and its fresh leaves are widely used as food flavoring in Asian cuisine. All parts of coriander plants are used as seasonings or as traditional remedies for various disorders in different civilizations [1]. Moreover, coriander leaves possess antioxidant properties. Phytochemicals, such as flavonoids, $\beta$-carotene, and phenolic compounds, are rich in coriander leaves [2-4]. Notably, ascorbic acid (ASA), carotenoids, chlorophylls, rutin (quercetin-3-rutinoside; $\mathrm{QR}$ ), and chlorogenic acid (CA) are the main class of natural antioxidants in plants [3,5]. Carotenoids and chlorophylls are natural pigments found in fruits, vegetables, and algae. Mammals cannot synthesize both carotenoids and chlorophylls; therefore, humans need to get them from foods or via supplementation. The pharmacology of carotenoids include eye and heart health, cancer prevention, skin protection, and fertility [6], while chlorophylls are strong combat anemia, stimulating immune system, anti-carcinogenic, anti-mutagenic, and purifying the blood $[7,8]$. 
Phenolic compounds are produced by plants mainly against the stress, and they have various functions relevant to human health, such as antioxidant activity, anti-bacterial, anti-allergenic, anti-thrombotic, and vasodilatory effects $[9,10]$. Phenolic compounds include two main groups, which are phenolic acids and flavonoids. In coriander foliage, the phenolic acids, including chlorogenic acid, vanillic acid, caffeic acid, ferulic acid, and $p$-coumaric acid, together with the flavonoids, including quercetin, kaempferol, apigenin, and luteolin, have been identified by chemical studies [4,5]. Among those compounds, QR is the major compound in coriander foliage [4]. QR is a common flavonoid and exists in various plants, such as tea leaves and apples; pharmacological activities of this flavonoid include antioxidant, cytoprotective, anticarcinogenic, and cardioprotective effects, etc. [11]. CA is composed of esters derived from caffeic acid and quinic acid and is abundantly found in plants, fruits, and vegetables, such as coffee beans, blueberries, and peanuts [12]. CA features strong antidiabetic and antilipidemic effects [13]. Thus, the contents of ASA, carotenoid, QR, CA, and total phenolic compounds in the plants are important for the applications of coriander in cooking and medical use.

Plant factories using artificial lighting are advanced indoor cultivation systems to grow plants in an environmentally controlled condition. Therefore, plant factories enable the application or suppression of stress conditions to plants for specific demands on shape, taste, and secondary metabolite content [14]. Among various environmental conditions, the root-zone temperature (RZT) is an important environmental factor for plant growth because it greatly affects various growth and physiological processes, such as mineral and water uptake, metabolic absorption, photosynthesis, stem and leaf growth, and bioactive compound accumulation [15-18].

Our previous study showed that high-quality coriander rich in secondary metabolite contents can be produced by maintaining a high RZT of $30{ }^{\circ} \mathrm{C}$ during cultivation [19]. High RZT causes drought in coriander plants, which increases the accumulation of secondary metabolites. However, the biomass decreases when the RZT is at $30^{\circ} \mathrm{C}$ compared with $25^{\circ} \mathrm{C}$. Falah et al. reported that the short-term high RZT improves the uptake of water and nutrients, whereas long-term high RZT inhibits the uptake of water and nutrients, reduces oxygen solubility, and increases the enzymatic oxidization of phenolic compounds in tomato [20]. Thus, we hypothesize that a short-term RZT stress treatment can enhance the biomass and secondary metabolite accumulation of coriander plants. A mid-temperature $\left(25^{\circ} \mathrm{C}\right)$ pre-treatment was applied during the early stage of cultivation, followed by low or high temperature stress treatments for different days before harvesting. This study aimed to find an appropriate combination of RZT and treatment time to enhance the secondary metabolite content in coriander plants without reducing biomass.

\section{Materials and Methods}

\subsection{Plant Material}

\subsubsection{Germination and Plant Seedling}

Coriander seeds were sown in sponge cubes $\left(2.3 \mathrm{~cm} \times 2.3 \mathrm{~cm} \times 2.8 \mathrm{~cm}, 14.8 \mathrm{~cm}^{3}\right)$ in a cultivation room. Germinated seeds were placed under a photosynthetic photon flux density (PPFD) of $150 \mu \mathrm{mol}$ $\mathrm{m}^{-2} \mathrm{~s}^{-1}$ with a photoperiod of $16 \mathrm{~h}$ per day using cool white fluorescent lamps (FHF32 EX-N-H, Panasonic, Co., Ltd., Niigata, Japan). The seedlings were irrigated with a nutrient solution (N 21\%, $\mathrm{P}_{2} \mathrm{O}_{5} 8 \%, \mathrm{~K}_{2} \mathrm{O} 27 \%$, MgO 4\%, CaO 23\%, Fe 0.18\%, Cu 0.002\%, Zn 0.006\%, Mo 0.002\%, MnO 0.1\%, $\mathrm{B}_{2} \mathrm{O}_{3}$ $0.1 \%$ ) (Otsuka hydroponic composition, OAT Agrio Co., Ltd., Tokyo, Japan) starting at 10 days after sowing. The electric conductivity (EC) and $\mathrm{pH}$ of the nutrient solution were adjusted to $0.6 \mathrm{dS} \mathrm{m}^{-1}$ and 6.0, respectively. The air temperature, relative humidity, and $\mathrm{CO}_{2}$ concentration were set to $25 / 22{ }^{\circ} \mathrm{C}$ (light/dark periods), 60-80\%, and $400 \mathrm{ppm}$, respectively. 


\subsubsection{Growth Condition and Treatments}

On day 17 after sowing, the seedlings were transplanted to the hydroponic system under the deep flow technique in a walk-in type plant factory $(2.9 \mathrm{~m} \times 2.0 \mathrm{~m} \times 2.3 \mathrm{~m}$ in length $\times$ weigth $\times$ height $)$ and subjected to a PPFD of $300 \mu \mathrm{mol} \mathrm{m} \mathrm{m}^{-2} \mathrm{~s}^{-1}$ with a photoperiod of $16 \mathrm{~h}$ per day using light-emitting diode lamps (GreenPower Production module, DR/W/FR, NL, Philips Co., Ltd., Piła, Poland). The PPFD was measured at $5 \mathrm{~cm}$ above the surface of the culture panels using a light meter (LI 250A, LI-190R; Li-Cor Inc., Lincoln, NE, USA) before transplanting. Coriander seedlings were grown at an RZT of $25^{\circ} \mathrm{C}$ for 18 days as a control. For treatments, 3 or 6 days of four RZTs $\left(15^{\circ} \mathrm{C}, 20^{\circ} \mathrm{C}, 30^{\circ} \mathrm{C}\right.$, and $\left.35^{\circ} \mathrm{C}\right)$ were applied to coriander seedlings at 12 or 15 days after transplanting (Figure 1). All coriander seedlings were grown at an RZT of $25^{\circ} \mathrm{C}$ before treatments were applied. Each treatment plot contained 32 plants (178 plants $\mathrm{m}^{-2}$ in plant density). RZTs of $15 \pm 0.5^{\circ} \mathrm{C}$ and $20 \pm 0.5^{\circ} \mathrm{C}$ were maintained by cooling the nutrient solution with a cool water circulator (ZR mini, Zensui Co., Ltd., Osaka, Japan). RZTs of $25 \pm 0.5^{\circ} \mathrm{C}, 30 \pm 0.5^{\circ} \mathrm{C}$, or $35 \pm 0.5^{\circ} \mathrm{C}$ were maintained by heating the nutrient solution using a heater (Type 100; Nisso, Marukan Ltd., Kanagawa, Japan). RZT was recorded by using a thermos recorder (TR-71wf, T\&D Corp., Nagano, Japan). The EC and pH of the nutrient solution were adjusted to $1.2 \mathrm{dS} \mathrm{m}^{-1}$ and 6.0, respectively. A new nutrient solution (1L) was added to each cultivation bed every day, and all nutrient solutions were renewed once a week. Air temperature, relative humidity, and $\mathrm{CO}_{2}$ concentration were set at $23 / 20^{\circ} \mathrm{C}$ (light/dark periods), $60-80 \%$, and 1000 ppter (Shimadzu, Kyoto, Japan) equipped with an electrosprm, respectively.

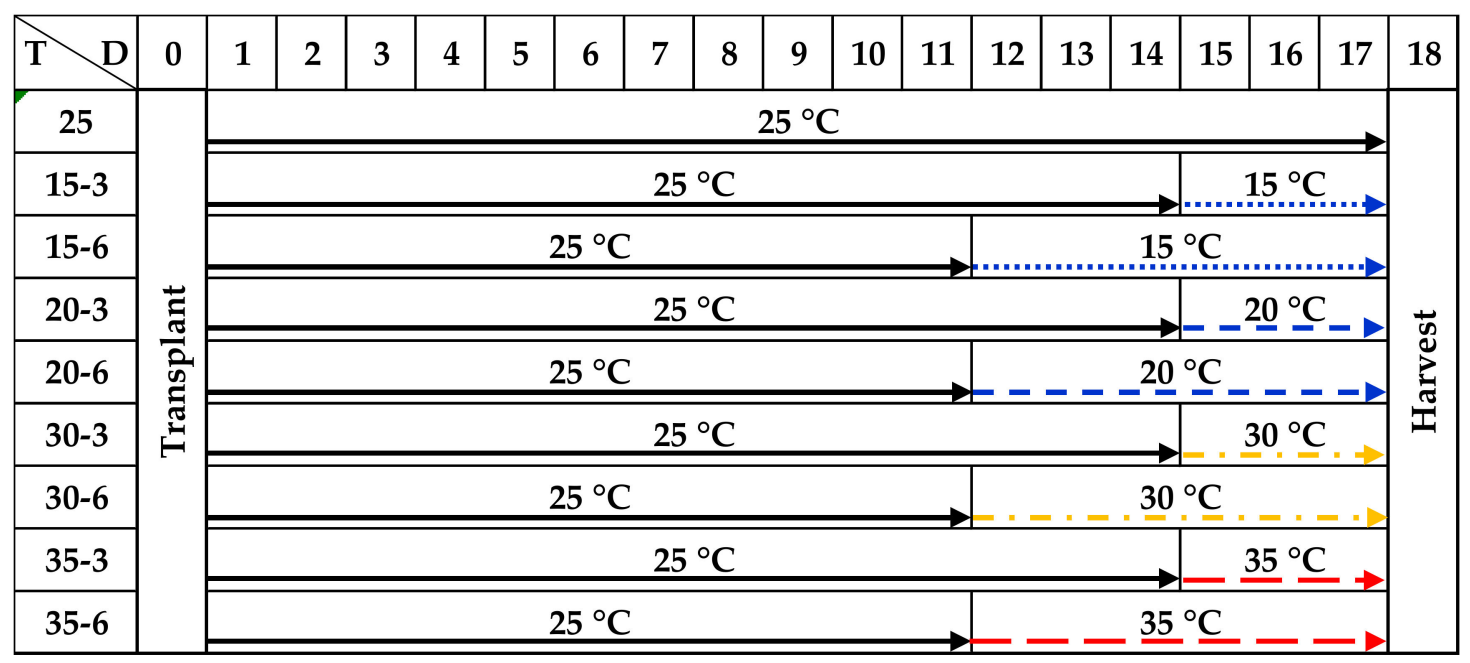

Figure 1. Root-zone temperature (RZT) regimes with different periods of temperature treatments during 18 days of cultivation. Treatment code (T): “25”, “15”, “20”, “30”, or "35" denotes an RZT of $25^{\circ} \mathrm{C}, 15^{\circ} \mathrm{C}, 20^{\circ} \mathrm{C}, 30^{\circ} \mathrm{C}$, or $35^{\circ} \mathrm{C}$, respectively; “ 3 " or " 6 " denotes stress period of 3 or 6 days, respectively. D: day of cultivation.

\subsection{Measurement}

\subsubsection{Growth Parameters}

The plants were harvested 18 days after transplanting. Leaf, stem, and root fresh weights (FWs) were determined at room temperature $\left(25^{\circ} \mathrm{C}\right)$. The leaf, stem, and root samples were placed in an $80^{\circ} \mathrm{C}$ oven for 1 week to determine their dry weights (DWs).

The water content (WC) of the shoots (\%) was calculated as

$$
W C=\frac{F W-D W}{F W} \times 100
$$

where FW and DW of the shoots were used. 


\subsubsection{Total Chlorophyll and Total Carotenoid Concentration}

The total chlorophyll (Chl) and total carotenoid concentrations were measured in biggest and youngest leaf tissues by extraction with $\mathrm{N}, \mathrm{N}$-dimethylformamide (DMF). A leaf disc with an area of $0.5 \mathrm{~cm}^{2}$ was placed into a glass vial containing $2.5 \mathrm{~mL}$ of DMF and immediately placed in darkness at $4{ }^{\circ} \mathrm{C}$ for $36 \mathrm{~h}$. The absorbance of the solution was then read on a spectrophotometer (SH-1300Lab, Corona Electric Co., Ltd., Ibaraki, Japan) at 663, 645, and $480 \mathrm{~nm}$ using DMF as a blank. The pigment concentrations were calculated using the following equations [21].

$$
\begin{gathered}
\mathrm{Chl}_{\mathrm{b}}(\mu \mathrm{g} \mathrm{mL}-1)=20.78 \mathrm{~A}_{647}-4.88 \mathrm{~A}_{664} \\
\text { Total Chl }\left(\mu \mathrm{g} \mathrm{mL} \mathrm{mL}^{-1}\right)=17.67 \mathrm{~A}_{647}+7.12 \mathrm{~A}_{664}, \\
\text { Total carotenoid }\left(\mu \mathrm{gL}^{-1}\right)=\left(1000 \mathrm{~A}_{480.0}-1.12 \mathrm{Chl}_{\mathrm{a}}-34.07 \mathrm{Ch}_{\mathrm{b}}\right) / 245 .
\end{gathered}
$$

\subsubsection{1,1-Diphenyl-2-picrylhydrazyl Radical-Scavenging Activity}

A $1 \mathrm{~g}$ of frozen shoot segment was weighed accurately and homogenized with $5 \mathrm{~mL}$ of $80 \%(v / v)$ methanol for $1 \mathrm{~min}$. The sample was centrifuged at $10,000 \times g$ for $30 \mathrm{~min}$ at $4{ }^{\circ} \mathrm{C}$. The supernatant was transferred to a $10 \mathrm{~mL}$ graduated cylinder, made up to $6 \mathrm{~mL}$ total with $80 \%$ methanol, and then stored at $-30{ }^{\circ} \mathrm{C}$ until analysis.

The antioxidant activity of the sample, based on the scavenging activity of 1,1-diphenyl2-picrylhydrazyl (DPPH), was determined through spectrophotometry in accordance with a previously described method [22,23] with some modifications. A $50 \mu \mathrm{L}$ aliquot of the test sample or Trolox solution $(0,200,400,600,800$, and $1000 \mu \mathrm{M})$ was added to $2 \mathrm{~mL}$ of a DPPH solution $(80 \mu \mathrm{M})$ in methanol and mixed thoroughly at room temperature. Absorbance at $517 \mathrm{~nm}$ was determined after $30 \mathrm{~min}$ in darkness using a spectrophotometer (ASV11D, As One, Corp. Osaka, Japan). The results were expressed as milligram Trolox equivalents per gram fresh weight $\left(\mathrm{mg} \mathrm{TE}^{-1} \mathrm{FW}\right)$.

\subsubsection{Total Phenolic Content}

Total phenolic content (TPC) of the sample described in 2.2.2 was measured using the Folin-Ciocalteu colorimetric assay [22-24] with gallic acid as calibration standard by using a spectrophotometer (ASV11D, As One, Corp. Osaka, Japan). A $0.25 \mathrm{~mL}$ aliquot of the test sample or gallic acid solution $\left(0,0.05,0.1,0.15,0.2,0.25\right.$, and $\left.0.3 \mathrm{mg} \mathrm{mL}^{-1}\right)$ was added to $1.25 \mathrm{~mL}$ of $10 \%$ Folin-Ciocalteu reagent, followed by $1 \mathrm{~mL}$ of $7.5 \%$ sodium carbonate solution, and then this was mixed thoroughly at room temperature. Absorbance at $765 \mathrm{~nm}$ was determined after $1 \mathrm{~h}$. The results were expressed as milligram gallic acid equivalents per gram fresh weight (mg GAE $\left.\mathrm{g}^{-1} \mathrm{FW}\right)$.

\subsubsection{Chlorogenic Acid and Rutin Content}

Measurement of CA and $\mathrm{QR}$ contents was conducted using a high-performance liquid chromatography (HPLC) (Shimadzu, Kyoto, Japan) equipped with a mass spectrometry (MS) (Shimadzu, Kyoto, Japan) as described previously [19]. Dried leaves and stems (30 ${ }^{\circ} \mathrm{C}, 4$ weeks) were chopped and weighted accurately (15.00-15.50 mg). The sample was mixed with methanol $(1 \mathrm{~mL})$ in a $1.5 \mathrm{~mL}$ tube and extracted for $10 \mathrm{~min}$ at $15^{\circ} \mathrm{C}$ with $2000 \mathrm{rpm}$ using a ThermoMixer $\mathrm{C}$ (Eppendorf, Hamburg, Germany). The mixture was centrifuged and the solution was decanted to a $5 \mathrm{~mL}$ volumetric flask. The same extraction was repeated two more times. Combined solutions (about $3 \mathrm{~mL}$ ) were diluted with methanol to a $5 \mathrm{~mL}$ total volume and filtered through a nylon syringe filter $(0.22 \mu \mathrm{m}$, TORAST Disc, Shimadzu GLC Ltd., Tokyo, Japan). The HPLC for CA and QR contents was performed on a LC-20A Prominence system (Shimadzu, Kyoto, Japan) with a LCMS-2020 mass spectrometer (Shimadzu, Kyoto, Japan) equipped with an electrospray ionization source. The negative ion monitoring mode was used for the detection for $[\mathrm{M}-\mathrm{H}]^{-}$of CA at $m / z 353$ and QR at $m / z 609$. The MS conditions was set as described previously [25]. A $1 \mu \mathrm{L}$ of the HPLC sample solution was 
injected onto an XBridge BEH C18 column $(3.5 \mu \mathrm{m}, 2.1 \times 150 \mathrm{~mm}$, Waters, Milford, MA, USA) at $35^{\circ} \mathrm{C}$ (column temperature) in $0.2 \mathrm{~mL} \mathrm{~min}^{-1}$ (flow rate) with solvents, $\mathrm{A}(0.1 \%$ formic acid, $v / v)$ and $\mathrm{B}$ (acetonitrile). The elution was started from 10\% B (0 min) to 20\% B (0-5 min), and 20\% B (5-10 min), then 10\% B (10-20 min). QR (quercetin 3-rutinoside trihydrate, analytical standard) was purchased from Sigma-Aldrich Japan (Tokyo, Japan). CA (pharmaceutical reference standard) was obtained from ChromaDex Inc. (Los Angeles, CA, USA). The QR and CA standard solutions were prepared as methanol solutions and used for identification and quantification. The CA and QR contents per unit of leaf/stem DW $\left(\mathrm{mg} \mathrm{g}^{-1}\right)$ were provided by dividing the CA and QR contents in the samples by the weight of the samples.

\subsection{Statistical Analysis}

Sixteen plants were sampled from each treatment to evaluate the overall growth parameters, and eight plants were sampled from each treatment to measure the total chlorophyll (Chl) content, total carotenoid content, ASA content, TPC, antioxidant capacity, and CA and QR contents. The analyses were performed with a SPSS statistical software (IBM SPSS Statistics, Version 25.0. Armonk, NY, USA: IBM Corp.). The parametric one-way analysis of variance was utilized to assess any differences among the treatment groups, and post-hoc analysis was performed with Tukey's test. The nonparametric Kruskal-Wallis test was used to test for significant differences among the treatment groups for CA and $\mathrm{QR}$, and the Dunn's multiple comparison test was applied when appropriate. Statistical significance was considered at $p<0.05$.

\section{Results}

\subsection{Plant Growth}

After 18 days of cultivation under the nine treatments, we observed the differences in the morphology and the growth of coriander plants (Figure 2). The leaf area decreased when short-term RZT stress was applied, comparing with that of the control (RZT: $25^{\circ} \mathrm{C}$, no change in RZT), with the exception of the treatment $30-3$ (RZT: $30^{\circ} \mathrm{C}, 3$ days) (Figure $3 \mathrm{~A}$ and Table S1). The shoot length was neither significantly affected by RZTs of $30^{\circ} \mathrm{C}$ and $20^{\circ} \mathrm{C}$ nor by $15^{\circ} \mathrm{C}$ for 3 days compared with that of the control (Figure 3B, Table S1). However, the shoot length strongly decreased when the plants were treated with an RZT of $35^{\circ} \mathrm{C}$ for 3 and 6 days, and an RZT of $15^{\circ} \mathrm{C}$ for 6 days before harvesting (Figure 3B).

Regardless of stress period ( 3 or 6 days), the leaf FW was decreased significantly by RZT 35, 30, 20, and 15, compared with the control (Figure 4A, Table S1). The stem FW responded similarly except for the treatment 30-3, which was no significant difference as the control (Figure 4B, Table S1). The leaf DW was significantly reduced by treatments 35-6, 30-3, 20-6, and 20-3 (Figure 4C, Table S1), and the stem DW was significantly reduced by treatments 35-6, 35-3, and 15-3 (Figure 4D, Table S1), compared with those of the control, respectively. 


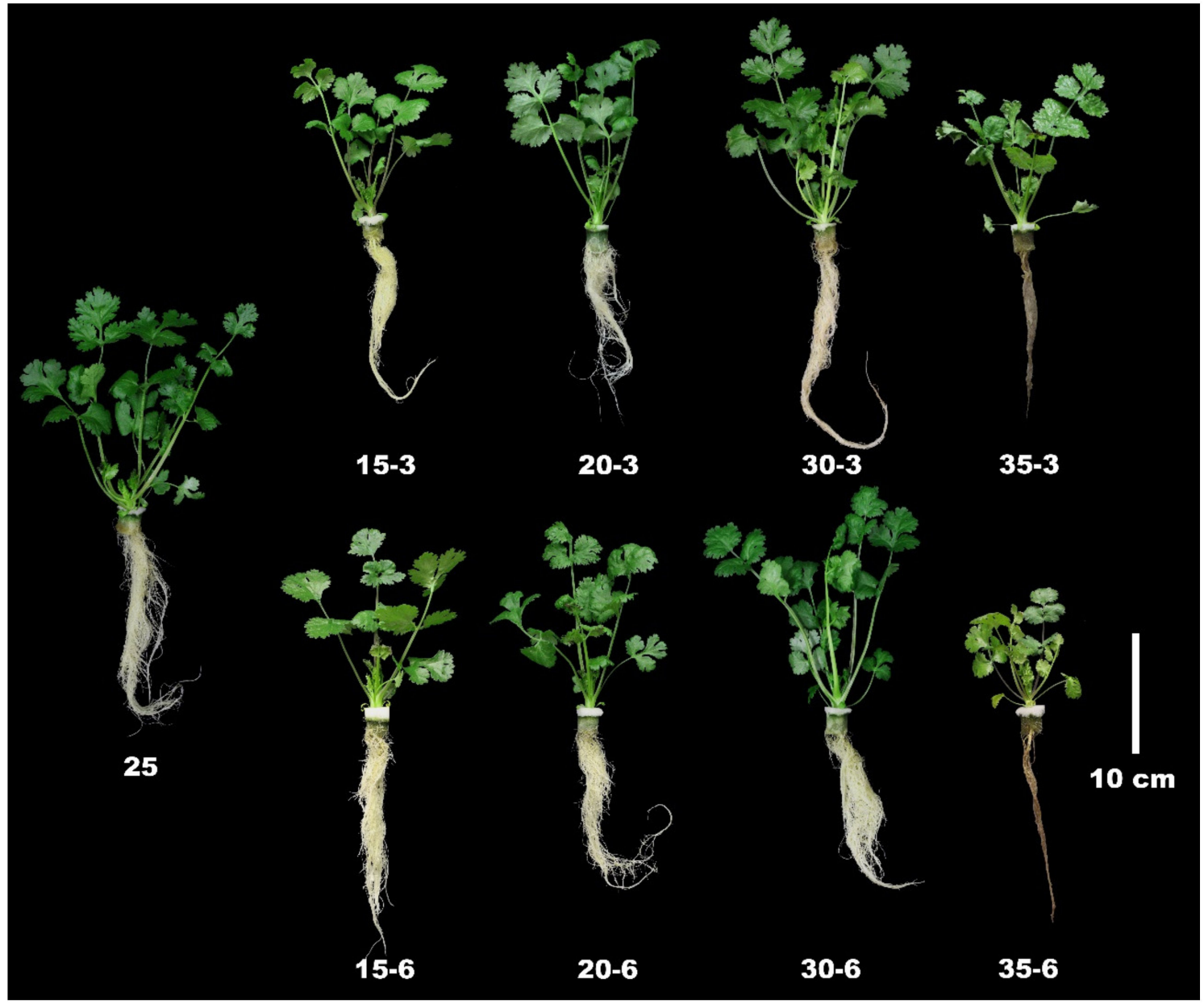

Figure 2. Coriander plants grown under nine different combinations of RZT and stress period for 18

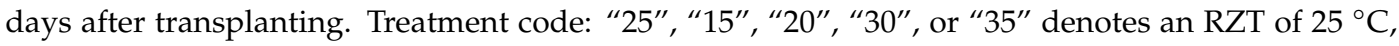
$15^{\circ} \mathrm{C}, 20^{\circ} \mathrm{C}, 30^{\circ} \mathrm{C}$, or $35^{\circ} \mathrm{C}$, respectively; “ 3 " or " 6 " denotes stress period of 3 or 6 days, respectively.

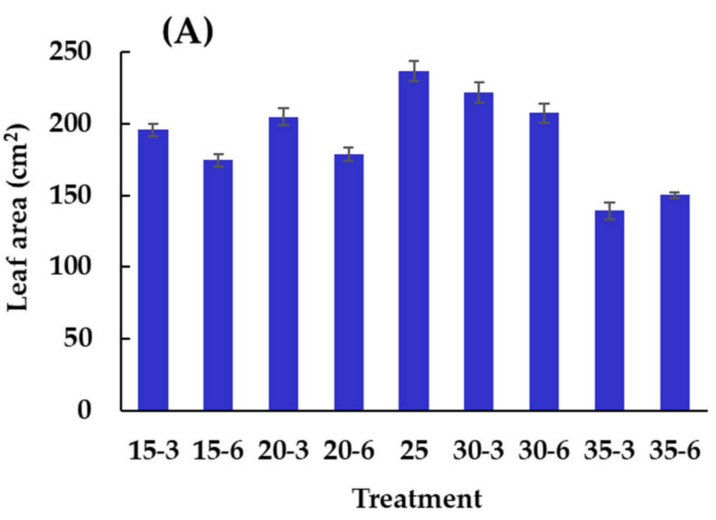

(B)

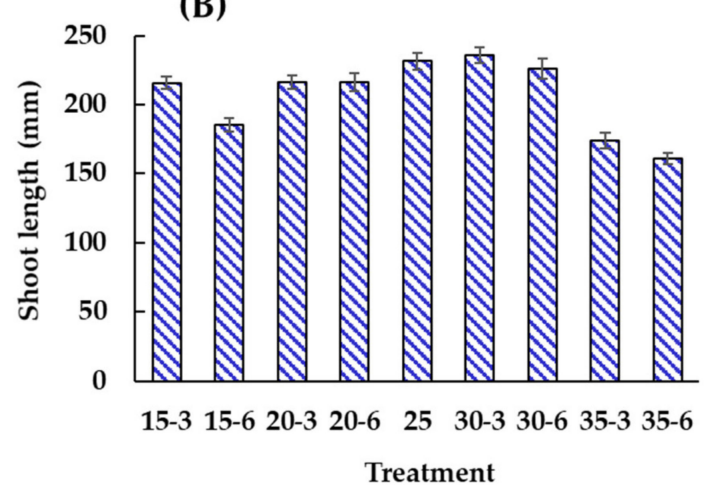

Figure 3. Leaf area (A) and shoot length (B) of coriander on day 18 after transplanting under different root-zone temperatures and stress periods. Data are shown as mean $\pm \mathrm{SE}, n=16$. 

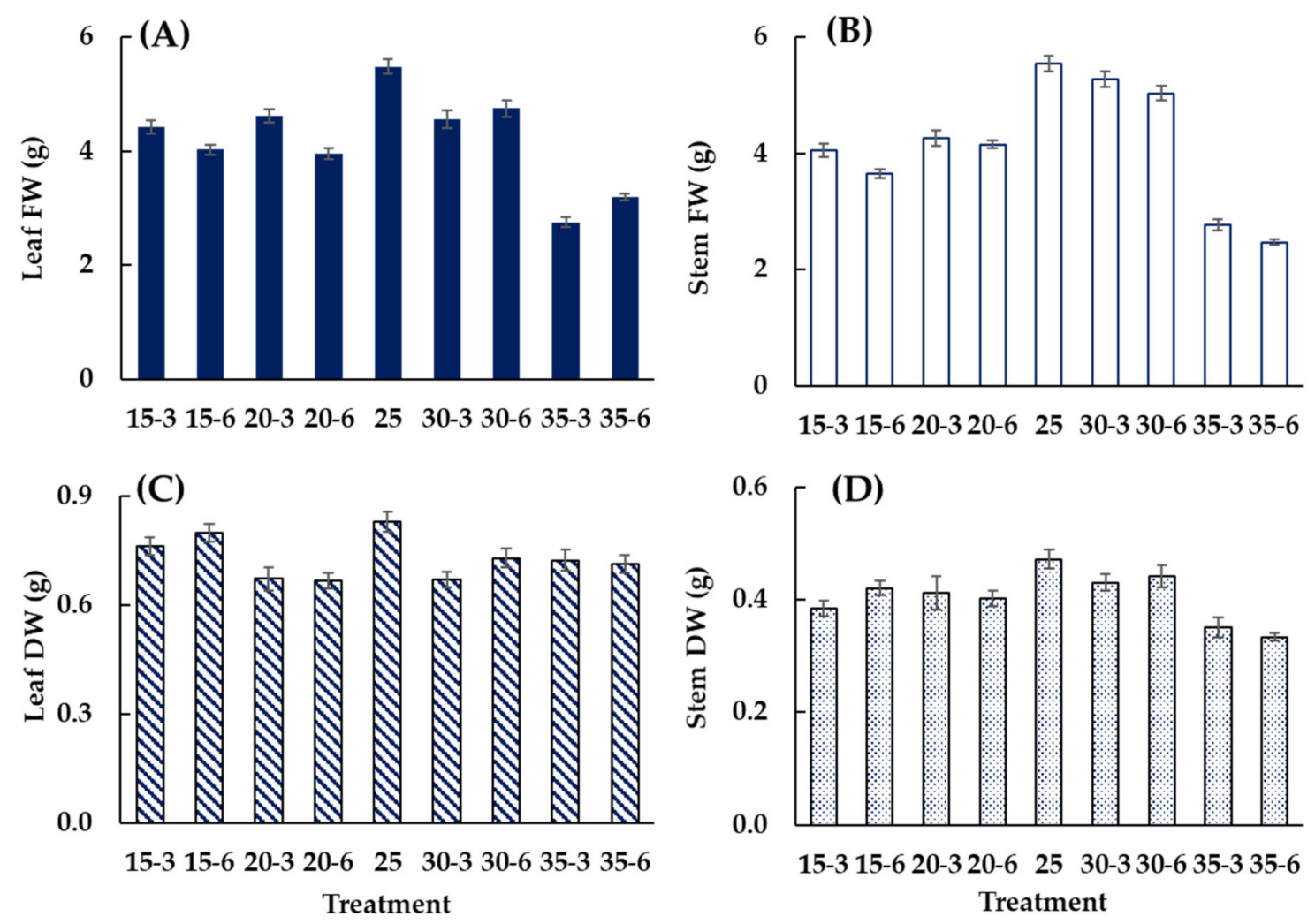

Figure 4. Fresh weight (FW) of leaves (A) and stems (B), dry weight (DW) of leaves (C) and stems (D) of corianders on day 18 after transplanting under different root-zone temperatures and stress periods. Data are shown as mean $\pm \mathrm{SE}, n=16$.

The root DWs under the control and treatment 15-6 were significantly higher than those under the other treatments (Figure 5A, Table S1). The lowest root DW was obtained under an RZT of $35^{\circ} \mathrm{C}$ for both treatment periods (Figure 5A). The shoot WCs of coriander in the control, treatments 30-6 and 30-3 were significantly higher than those in the other treatments, except for treatment 20-3 (Figure 5B, Table S1). The lowest shoot WC was obtained under an RZT of $35^{\circ} \mathrm{C}$ for both treatment periods (Figure 5B).
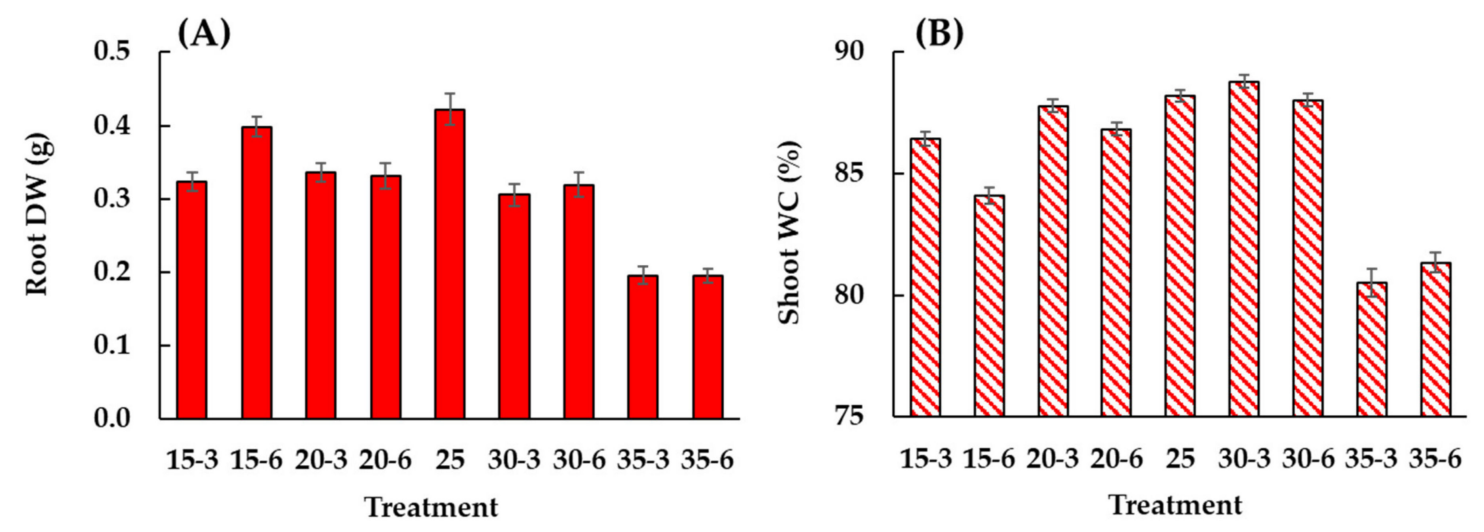

Figure 5. Root dry weight (A) and shoot water content (WC) (B) of coriander on day 18 after transplanting under different root-zone temperatures and stress periods. Data are shown as mean $\pm \mathrm{SE}$, $\mathrm{n}=16$. 
There was interaction effect between the two factors for the leaf area, shoot length, leaf FW, root DW, and shoot WC, respectively. However, there was no interaction effect between the two factors for the stem FW and leaf and stem DWs (Tables S1 and S2).

\subsection{Pigment, Secondary Metabolite, and Antioxidant Capacity}

The accumulated amounts of pigments, secondary metabolites and antioxidant capacity with the result of statistical analyses are listed in Table 1, Tables S3 and S4. The different treatments showed no significant difference in the total chlorophyll content. The highest total carotenoid content was observed in treatment 20-6, followed by 15-3, and the total carotenoid contents in the other treatments were significantly lower than that in 20-6. The highest ASA content was observed in treatment 15-3, 15-6 and 35-3, and significantly higher than that in treatment 20-3 and the control. TPC and antioxidant capacity were significantly increased by RZTs of $35^{\circ} \mathrm{C}$ and $15^{\circ} \mathrm{C}$ at both stress periods. The highest values for TPC and antioxidant activity were obtained in treatment 35-6. The TPC of the coriander plants under the control (RZT 25) was lower than those under the other treatments, except for treatment 30-3. However, the antioxidant capacities of the coriander plants under treatments 25, 30-3, 30-6, and 20-3 were similar.

Table 1. Total chlorophyll (Chl), total carotenoid, ascorbic acid (ASA), total phenolic contents (TPC), and antioxidant capacity in coriander on day 18 after transplanting under different root-zone temperatures and stress periods.

\begin{tabular}{|c|c|c|c|c|c|}
\hline $\begin{array}{l}\text { Treatment } \\
\text { Code }^{z}\end{array}$ & $\begin{array}{c}\text { Total Chl } \\
\text { Content } \\
\left(\mathrm{mg} \mathrm{g}^{-1} \mathrm{FW}\right)\end{array}$ & $\begin{array}{c}\text { Total } \\
\text { Carotenoid } \\
\text { Content } \\
\left(\mathrm{mg} \mathrm{g}^{-1} \mathrm{FW}\right)\end{array}$ & $\begin{array}{l}\text { ASA Content } \\
\quad\left(\mathrm{mg} \mathrm{g}^{-1}\right)\end{array}$ & $\begin{array}{c}\text { TPC } \\
\text { (mg GAE } \\
\mathrm{g}^{-1} \text { FW) }\end{array}$ & $\begin{array}{c}\text { Antioxidant } \\
\text { Capacity } \\
\left(\mathrm{mg} \mathrm{TE}^{-1} \text { FW) }\right.\end{array}$ \\
\hline 25 (control) & $0.95 \mathrm{abc}^{\mathrm{x}}$ & $0.16 \mathrm{c}$ & $1.59 \mathrm{~d}$ & $0.60 \mathrm{f}$ & $0.39 \mathrm{~d}$ \\
\hline $15-3$ & $1.08 \mathrm{ab}$ & $0.19 \mathrm{ab}$ & $1.91 \mathrm{a}$ & $0.84 \mathrm{~d}$ & $0.72 \mathrm{c}$ \\
\hline $15-6$ & $0.9 \mathrm{bc}$ & $0.16 \mathrm{bc}$ & $1.79 \mathrm{abc}$ & $1.11 \mathrm{c}$ & $1.04 \mathrm{~b}$ \\
\hline $20-3$ & $0.94 \mathrm{bc}$ & $0.16 \mathrm{bc}$ & $1.35 \mathrm{e}$ & $0.72 \mathrm{de}$ & $0.49 \mathrm{~d}$ \\
\hline $20-6$ & $1.12 \mathrm{ab}$ & $0.21 \mathrm{a}$ & $1.65 \mathrm{bcd}$ & $0.83 \mathrm{~d}$ & $0.66 \mathrm{c}$ \\
\hline $30-3$ & $1.12 \mathrm{ab}$ & $0.16 \mathrm{c}$ & $1.59 \mathrm{~cd}$ & 0.66 ef & $0.41 \mathrm{~d}$ \\
\hline $30-6$ & $1.16 \mathrm{a}$ & $0.17 \mathrm{bc}$ & $1.62 \mathrm{~cd}$ & 0.73 de & $0.44 \mathrm{~d}$ \\
\hline $35-3$ & $0.82 c$ & $0.16 \mathrm{c}$ & $1.83 \mathrm{ab}$ & $1.38 \mathrm{~b}$ & $1.12 \mathrm{~b}$ \\
\hline $35-6$ & $0.79 \mathrm{c}$ & $0.16 \mathrm{c}$ & $1.63 \mathrm{~cd}$ & $1.73 \mathrm{a}$ & $1.54 \mathrm{a}$ \\
\hline \multicolumn{6}{|l|}{ ANOVA $^{\mathrm{y}}$} \\
\hline RZT (A) & $* * *$ & $* * *$ & $* * *$ & $* * *$ & $* * *$ \\
\hline Stress period (B) & NS & $*$ & NS & $* * *$ & $* * *$ \\
\hline$A \times B$ & $* *$ & $* * *$ & $* * *$ & $* * *$ & $* * *$ \\
\hline
\end{tabular}

${ }^{\mathrm{z}}$ Treatment code, left numbers " 25 ", " $15^{\prime \prime}$, " $20^{\prime \prime}$, " $30^{\prime}$, and " $35^{\prime \prime}$ represent root-zone temperatures (RZTs) of $25^{\circ} \mathrm{C}$, $15^{\circ} \mathrm{C}, 20^{\circ} \mathrm{C}, 30^{\circ} \mathrm{C}$, and $35^{\circ} \mathrm{C}$, respectively, and right numbers " 3 " and " 6 " represent a stress period of 3 and 6 days, respectively. ${ }^{\mathrm{y}}$ Results of two-way analysis of variance (ANOVA) are shown. NS, non-significant. Asterisks show the significance of factors/interaction for: ${ }^{* * *} p<0.001 ; * * p<0.01 ;{ }^{*} p<0.05$. ${ }^{*}$ Data are shown as means $(n=8)$. The different letters in each column indicate significant differences between the treatments at $p<0.05$, determined by Tukey's test.

\subsection{Chlorogenic Acid and Rutin}

The highest CA content in the leaves was recorded in treatment $35-6$, and it was significantly higher than any of the contents in RZTs of $20^{\circ} \mathrm{C}, 25^{\circ} \mathrm{C}$, and $30^{\circ} \mathrm{C}$ (Figure $6 \mathrm{~A}$, Table S5). Treatments 15-3, 35-3, and 35-6 increased the CA content in the leaves significantly compared with the control, but significant difference was observed between the treatment groups in RZTs of $15^{\circ} \mathrm{C}$ and $35^{\circ} \mathrm{C}$. The CA content in the stems significantly increased under treatments 35-6 and 15-6 compared with the control 
(Figure 6B, Table S5). Regardless of period, RZTs of $15^{\circ} \mathrm{C}$ and $35^{\circ} \mathrm{C}$ increased significantly the CA content per plant compared with the control (Figure 6C, Table S5). The CA content per plant became the highest in the coriander plants grown under RZT $35^{\circ} \mathrm{C}$ for last 6 days and reached $5.41 \mathrm{mg}$ per plant in dry weight It was significantly higher than any of those in RZTs of $20^{\circ} \mathrm{C}, 25^{\circ} \mathrm{C}$, and $30{ }^{\circ} \mathrm{C}$ but not significantly compared with the groups under treatments 15-3, 15-6, and 35-3.
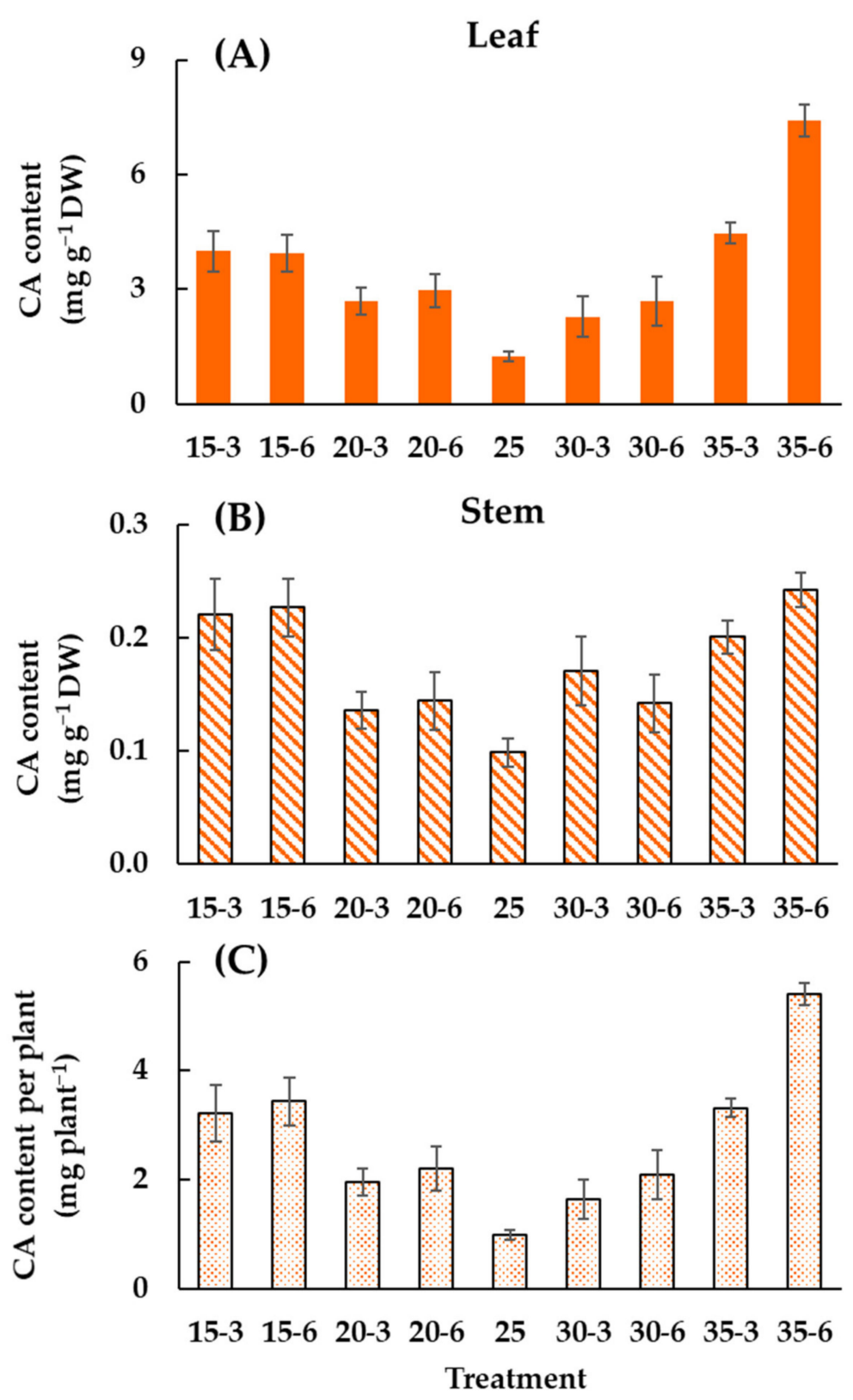

Figure 6. Chlorogenic acid (CA) content per unit of leaf dry weight (DW) (A), CA content per unit of stem DW (B), and CA content per plant (C) in coriander plants after 18 days of cultivation under different root-zone temperatures and stress periods. Data are shown as the mean $\pm \mathrm{SE}, n=8$.

The QR content in the leaves was raised with treatments, but the changes were not statistically significant between treatment groups (Figure 7A and Table S6). The QR content in the stems was increased significantly by treatment 35-6 or 15-6 compared with any of the control, 30-3 and 30-6 (Figure 7B and Table S6). The greatest level of the QR content in the stems was obtained with treatments 35-6 and 15-6. Changing the RZT enhanced the QR content per plant, but the effect was not significant (Figure 7C and Table S6). 

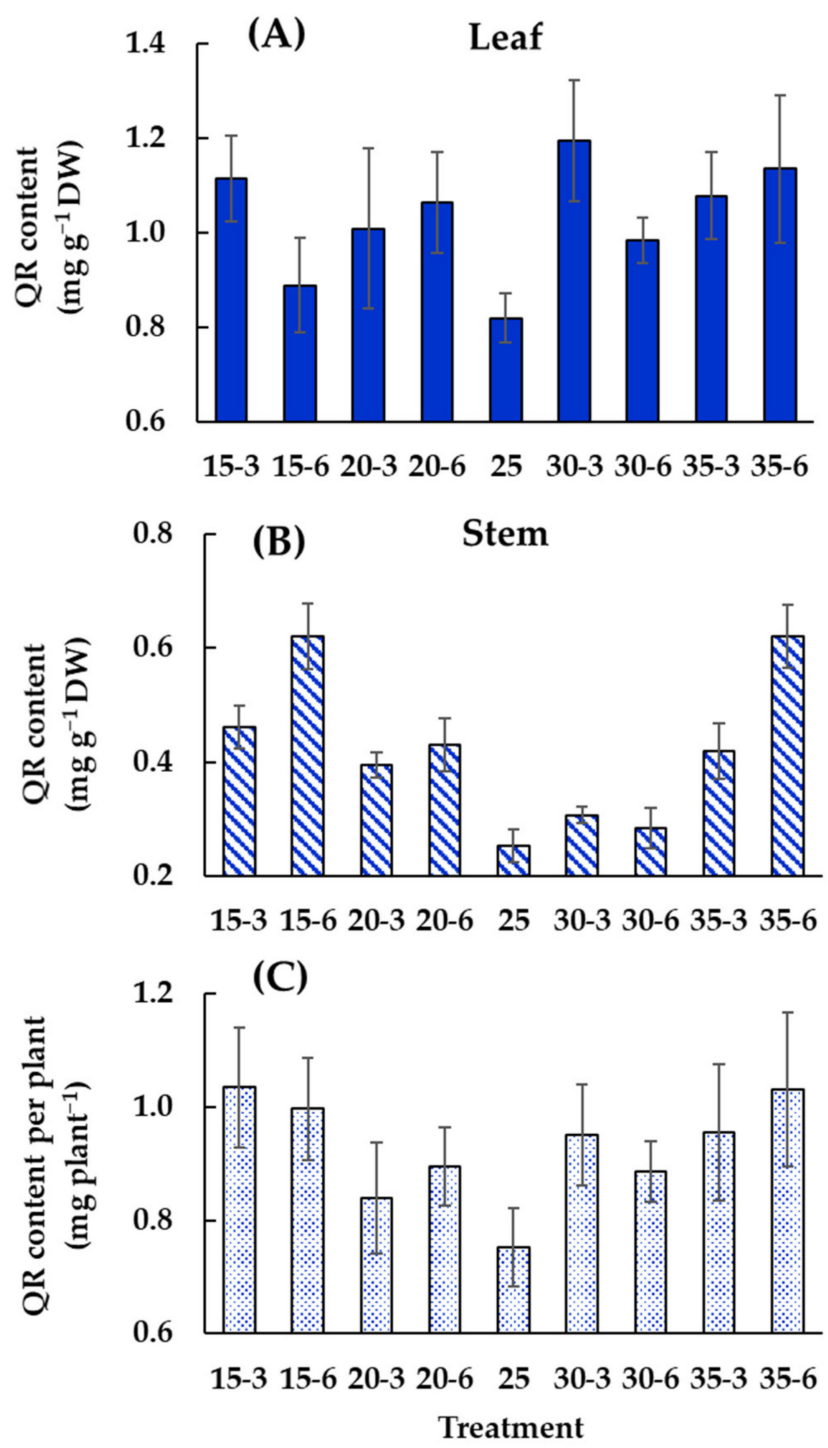

Figure 7. Rutin (QR) content per unit of leaf dry weight (DW) (A), QR content per unit of stem DW (B), and $Q R$ content per plant $(C)$ in coriander plants after 18 days of cultivation under different root-zone temperatures and stress periods. Data are shown as the mean $\pm \mathrm{SE}, \mathrm{n}=8$.

\section{Discussion}

\subsection{Plant Growth}

The RZT is an important environmental factor that affects plant growth and phytochemical products. By affecting root growth and initiation, the RZT influences the physiological processes, such as the uptake of mineral nutrients and water, in the roots and the whole plant $[26,27]$. Our study showed that the root DW decreased rapidly when the RZT was increased from $25{ }^{\circ} \mathrm{C}$ to $35^{\circ} \mathrm{C}$ or decreased from $25^{\circ} \mathrm{C}$ to $15{ }^{\circ} \mathrm{C}$ regardless of the stress period. As shown in Figure 2, under an RZT of $35^{\circ} \mathrm{C}$, the root system was poorly developed and could cause the poor uptake of minerals and water through the roots. This could lead to the relatively low WC in the shoots. The short-term application of low RZT $\left(15^{\circ} \mathrm{C}\right)$ also decreased the WC in the shoots of coriander. This result was similar to the results obtained by Sakamoto and Suzuki [15], who reported that the WC in the shoots of red leaf lettuce reduces with decreasing RZT and reaches the lowest level under an RZT of $10^{\circ} \mathrm{C}$.

As known, plants grow well when a plant established a synchronous development in all of its parts. Over time, undergrown roots may not supply enough water and nutrients for good shoot growth. 
In the present study, the shoot FW slightly reduced when the RZT was mildly increased from $25^{\circ} \mathrm{C}$ to $30^{\circ} \mathrm{C}$ but rapidly decreased under a more drastic increase in RZT (up to $35^{\circ} \mathrm{C}$ ) or under a decrease in RZT $\left(20^{\circ} \mathrm{C}\right.$ or $\left.15^{\circ} \mathrm{C}\right)$. The results also showed the effect of stress period on leaf and stem FW under low RZTs. The leaf and stem FWs significantly decreased when the stress period was extended from 3 days to 6 days. However, the stress period exerted no significant effect on leaf and stem DWs. These results indicated that RZT was more influential to coriander biomass accumulation than the length of the short-term stress period.

The stem FW of the coriander grown under low temperature was affected by the interaction of both factors. The leaf and stem DWs slightly decreased when short-term temperature stress was applied. This finding was consistent with the results of Chadirin et al. [28,29], who reported that applying 7 days of $5{ }^{\circ} \mathrm{C}$ or 3 days of $30^{\circ} \mathrm{C}$ RZT reduces the shoot DW of spinach. However, applying 7 days of $10{ }^{\circ} \mathrm{C}$ RZT and 6 days of $10^{\circ} \mathrm{C}, 12^{\circ} \mathrm{C}$, or $15^{\circ} \mathrm{C}$ RZT did not affect the DWs of red leaf lettuce [15] and red perilla [30] compared with $20^{\circ} \mathrm{C}$ RZT, respectively.

In addition, the leaf and stem DWs of coriander grown under an RZT of $30^{\circ} \mathrm{C}$ or $15^{\circ} \mathrm{C}$ for 6 days before harvesting showed no significant difference with the control treatment. However, the WC of the coriander in treatment RZT 15-6 rapidly decreased to a level lower than that of the coriander in the control treatment, whereas the WC of the coriander in treatment RZT 30-6 was not significantly different from that of the coriander in the control treatment. These data indicated that applying short-term RZT stress can affect the physiology and biomass accumulation in coriander. Increasing the RZT from $25^{\circ} \mathrm{C}$ to $30^{\circ} \mathrm{C}$ for 6 days before harvesting can produce coriander without reductions in biomass and WC compared with the plants under the control treatment. Conversely, roots of the coriander grown under treatments 35-6 and 35-3 turned brown and rot (Figure 2), and droopy leaves were observed 4 days and 1 day, respectively, after treatment of high RZT $\left(35^{\circ} \mathrm{C}\right)$ (data not shown). These results indicated that the adaptive capacity of small seedlings might be better than that of large ones. Moreover, the RZT also affects the uptake of nutrients and water differently by the crop [31]. Therefore, short-term RZT stress inhibits plant growth depending on the crop, the stage of the plant, and the treatment duration and temperature.

The RZT is directly related to the dissolved oxygen (DO) concentration in the nutrient solutions and the availability of oxygen by crops [18]. RZT stress (especially high RZT, such as $35^{\circ} \mathrm{C}$ ) limits DO levels in nutrient solution [20] thus the growth and yield of the plants grown in hydroponic systems. Oxygen deficiency in the root zone often causes heavy injuries in plant root and shoot functions [32]. It is reported that a high RZT $\left(30^{\circ} \mathrm{C}\right)$ reduced the oxygen consumption of the strawberry root and decreased root activity, which caused the plant to wither; however, a low RZT $\left(10^{\circ} \mathrm{C}\right)$ increased root weight of strawberry without enhancing biomass of leaves [33]. The root activity, macro and micro nutrients uptake, and water uptake could be also suppressed by RZT stress in the present study.

\subsection{Pigments and Secondary Metabolite Accumulation}

Plant pigments, especially chlorophylls and carotenoids, are important to plant growth and development. The amount of chlorophylls is largely affected by the surrounding environments. In our study, the total chlorophyll content in the coriander leaves showed no significant difference among the applied treatments. However, some studies suggested that low or high RZT reduces chlorophyll content in plants; for example, RZTs of $25^{\circ} \mathrm{C}$ and $10{ }^{\circ} \mathrm{C}$ decrease the chlorophyll contents of corn salad [34] and red romaine lettuce [35], respectively, compared with an RZT of $15^{\circ} \mathrm{C}$. Different from chlorophyll, carotenoids increased in content with decreasing RZT. Regardless of the stress period, the ASA content was also promoted when the plants were grown under an RZT of $15^{\circ} \mathrm{C}$. This result contrasted with the findings of Sakamoto and Suzuki [15] that the ASA content in red leaf lettuce is not affected by short-term low or high RZT.

Phenolics in plants are produced mainly against the stress from environmental factors (light, chilling, pollution, etc.), and to defense when injured [36]. In the present experiment, the heating or cooling of the roots may be sufficient to cause a stress response, considering that the plant biomass 
decreased while the TPC increased after root exposure to low or high temperature in a short duration (Table 1). Various abiotic and biotic factors induce the generation of reactive oxygen species (ROS) in plants leading to oxidative stress. Temperatures above or below the optimal levels may disrupt various cell functions $[27,37]$. Many studies have found that too low or high temperature may enhance the production of ROS, including singlet oxygen $\left({ }^{1} \mathrm{O}_{2}\right)$, superoxide $\left({ }^{\bullet} \mathrm{O}_{2}{ }^{-}\right)$, hydrogen peroxide $\left(\mathrm{H}_{2} \mathrm{O}_{2}\right)$, and hydroxyl radical $\left({ }^{\bullet} \mathrm{OH}\right)$. Plants cope with oxidative stress by synthesizing antioxidant metabolites, such as flavonoids and phenolic acid compounds [38]. This finding was in agreement with our previous study, which showed that TPC is enhanced under RZTs of $20{ }^{\circ} \mathrm{C}$ and $30{ }^{\circ} \mathrm{C}$ in comparison with $25^{\circ} \mathrm{C}$ [19]. In the present research, the TPC and antioxidant capacity of the plants under treatment 15-6 was enhanced while the biomass under this condition did not reduce in comparison with the control treatment. These results suggest that the short-term RZT stress plays an important role in increasing TPC and consequently enhancing antioxidant activity in coriander plants. In addition, the TPC and antioxidant capacity in the coriander grown under $30^{\circ} \mathrm{C}$ for 6 days were higher than those in the plant grown under $25^{\circ} \mathrm{C}$, but the difference in antioxidant capacity was not significant. Furthermore, the shoot WC significantly reduced after applying an RZT of $15{ }^{\circ} \mathrm{C}$ or $35^{\circ} \mathrm{C}$. This result indicates that coriander plants might be exposed to drought stress due to the poor water intake of the roots under an RZT of $15^{\circ} \mathrm{C}$ or $35^{\circ} \mathrm{C}$. Considering that drought stress triggers various secondary metabolite pathways, we hypothesized that the higher TPC value obtained from the corianders at an RZT of $15^{\circ} \mathrm{C}$ or $35^{\circ} \mathrm{C}$ in this experiment is a response to drought stress.

QR and CA are predominant phenolic compounds in coriander leaf/stem, and their contents in a plant are important due to their multiple positive effects on human health and their good antioxidant effects $[3,5,39]$.

The amount of $C A$ accumulated in the coriander leaves was higher than that of $Q R$ in all treatments, and the ratio of $C A$ to $Q R$ content in the leaves were different among treatments. In addition, the content of CA in the leaves significantly increased when short-term RZTs were applied, whereas no significant difference in QR content was found among the treatments. Thus, these results indicate that CA biosynthesis in coriander leaves is more sensitive to environmental changes than $\mathrm{QR}$ synthesis. In addition, the effect of changing the RZT from $25^{\circ} \mathrm{C}$ to the other levels appeared positively on the CA content regardless of the stress period (Figure 6). Therefore, we consider that the accumulation of $\mathrm{CA}$ in coriander plant is strongly sensitive to changes in RZT. Thus, the control of RZT during cultivation can effectively produce corianders with greater amounts of CA than usual. In other words, we suppose that stimuli from RZT for a short duration before harvesting could induce the biosynthesis of CA optimally in coriander leaves.

The differences between treatments in CA content per plant (Figure 6C) showed a similar trend to those in CA content in the leaves (Figure 6A). The similarity between the content in leaf $(X)$ and per plant $(\mathrm{Y})$ was tested with simple regression analysis, and a significant association was found between $\mathrm{X}$ and $\mathrm{Y}\left(r=0.962, \mathrm{Y}=0.733 \mathrm{X}+0.112, F(1,70)=879.208, p=0.000<0.05, R^{2}=0.926\right.$, Figure S1A). This result indicates that regardless of the treatments, the CA yield $(\mathrm{Y})$ could be determined by leaf concentration $(\mathrm{X})$, and the leaves make a larger contribution to the accumulation of $\mathrm{CA}$ than the stems in a coriander plant. This explanation is also applicable to $\mathrm{QR}$ accumulation in plants (Figure 7A,C) when the similar relationship around the $\mathrm{QR}$ content was tested using regression analysis between the content in leaf $(\mathrm{X})$ and per plant $(\mathrm{Y}), r=0.856, \mathrm{Y}=0.713 \mathrm{X}+190.58, F(1,70)=192.669, p=0.000<0.05$, $R^{2}=0.734$ (Figure S1B). However, in the stems, the content of $Q R$ was higher than that of CA regardless of the treatment, and the RZT effect on the QR content was significant in the stems. Therefore, the goodness of fit for the QR model was lower than that for the CA model (Figure S1). We speculate that short-term RZT stress influences the distribution and accumulation of QR in the stems rather than the biosynthesis of $\mathrm{QR}$ in the leaves. 


\section{Conclusions}

This research investigated the effects of short-term RZT on the secondary metabolite accumulation and growth of coriander. Results showed that secondary metabolite production was strongly influenced by the interaction between RZT and short-term stress period. The growth of coriander plants was slightly reduced under stress condition. In contrast, the accumulation of secondary metabolites, including ASA, carotenoids, phenolic compounds, rutin, and CA, and the antioxidant capacity of coriander plants were enhanced with the combination of the lowest or highest RZT $\left(15^{\circ} \mathrm{C}\right.$ or $\left.35^{\circ} \mathrm{C}\right)$ and longer stress period ( 6 days). The leaf and stem FWs and DWs of the coriander grown under an RZT of $30^{\circ} \mathrm{C}$ for 6 days slightly decreased compared with those of the coriander grown under the control treatment, but the TPC and CA contents per plant were higher under an RZT of $30^{\circ} \mathrm{C}$ than under the control treatment. Therefore, applying an RZT of $30^{\circ} \mathrm{C}$ for 6 days produces corianders containing large amounts of phenolics, including CA, without a loss of biomass, and applying an RZT of $15^{\circ} \mathrm{C}$ for 6 days produces corianders with a high amount of dry biomass, good antioxidant capacity, and high contents of secondary metabolites. Different regulation strategies can be selected to produce corianders with different qualities for cooking, seasoning, or medicine.

Supplementary Materials: The following are available online at http://www.mdpi.com/2073-4395/10/3/413/s1, Table S1. Leaf area, shoot length, leaf and stem fresh weight (FW), leaf, stem and root dry weight (DW), and shoot water content (WC) of coriander on day 18 after transplanting under different root-zone temperatures and stress periods; Table S2. Analysis of variance for growth parameters (Leaf area, shoot length, fresh weight (FW), dry weight (DW), and shoot water content (WC) in coriander plants cultivated for 18 days under eight combinations of two factors: four levels of root-zone temperature (RZT) and two levels of stress period; Table S3. Total chlorophyll (Chl), total carotenoid, ascorbic acid (ASA), total phenolic contents (TPC), and antioxidant capacity in coriander on day 18 after transplanting under different root-zone temperatures and stress periods; Table S4. Analysis of variance for total chlorophyll (Chl), total carotenoid, ascorbic acid (ASA), total phenolic contents (TPC), and antioxidant capacity in coriander plants cultivated for 18 days under eight combinations of two factors: four levels of root-zone temperature (RZT) and two levels of stress period; Table S5. Pairwise comparisons between treatments for chlorogenic acid (CA) content per unit of leaf dry weight (DW) (A), CA content per unit of stem DW (B), and CA content per plant (C) in coriander plants. Dunn's tests for multiple comparisons following a Kruskal -Wallis test were used to compare treatment 1 and treatment 2. Two-sided $p$-values for each pairwise comparison were adjusted by a Bonferroni correction method and statistical significance was set at ${ }^{*} p<0.05$; Table S6. Pairwise comparisons between treatments for rutin (QR) content per unit of leaf dry weight (DW) (A), QR content per unit of stem DW (B), and QR content per plant (C) in coriander plants. Dunn's tests for multiple comparisons following a Kruskal -Wallis test were used to compare treatment 1 and treatment 2 . Two-sided $p$-values for each pairwise comparison were adjusted by a Bonferroni correction method and statistical significance was set at ${ }^{*} p<$ 0.05; Figure S1. Scatter plots for the relationship between CA contents of leaves and plants (A); and QR contents (B) with a regression line. The correlation was tested by simple regression analysis. [X]: the content in leaf; [Y]: the content per plant.

Author Contributions: D.T.P.N., N.L. and M.T. conceived and designed the experiments. D.T.P.N. and M.K. performed the experiments. D.T.P.N. and N.K. analyzed the data and prepared figures and graphs. M.T. and N.K. contributed reagents, materials, and analysis tools. D.T.P.N., N.L. and N.K. prepared the manuscript, and all the members contributed extensively to its finalization. All authors have read and agreed to the published version of the manuscript.

Acknowledgments: This work was partially supported by JSPS KAKENHI Grant Number JP18H02301, and Chiba University Institute for Global Prominent Research.

Conflicts of Interest: There are no conflicts of interest to declare.

\section{References}

1. Sahib, N.G.; Anwar, F.; Gilani, A.H.; Hamid, A.A.; Saari, N.; Alkharfy, K.M. Coriander (Coriandrum sativum L.): A potential source of high-value components for functional foods and nutraceuticals-A review. Phyther. Res. 2013, 27, 1439-1456.

2. Kohara, K.; Sakamoto, Y.; Hasegawa, H.; Kozuka, H.; Sakamoto, K.; Hayata, Y. Fluctuations in volatile compounds in leaves, stems, and fruits of growing coriander (Coriandrum sativum L.) plants. J. Jpn. Soc. Hortic. Sci. 2006, 75, 267-269. [CrossRef]

3. Divya, P.; Puthusseri, B.; Neelwarne, B. The effect of plant regulators on the concentration of carotenoids and phenolic compounds in foliage of coriander. LWT Food Sci. Technol. 2014, 56, 101-110. [CrossRef] 
4. El-Zaeddi, H.; Calín-Sánchez, Á.; Nowicka, P.; Martínez-Tomé, J.; Noguera-Artiaga, L.; Burló, F.; Wojdyło, A.; Carbonell-Barrachina, Á.A. Preharvest treatments with malic, oxalic, and acetylsalicylic acids affect the phenolic composition and antioxidant capacity of coriander, dill and parsley. Food Chem. 2017, 226, 179-186. [CrossRef] [PubMed]

5. Barros, L.; Dueñas, M.; Dias, I.M.; Maria, S.J.; Santos-buelga, C.; Ferreira, I.C.F.R. Phenolic profiles of in vivo and in vitro grown Coriandrum sativum L. Food Chem. 2012, 132, 841-848. [CrossRef]

6. Eggersdorfer, M.; Wyss, A. Carotenoids in human nutrition and health. Arch. Biochem. Biophys. 2018, 652, 18-26. [CrossRef]

7. İnanç, A.L. Chlorophyll: Structural properties, health benefits and its occurrence in virgin olive oils. Acad. Food J./Akademik GIDA 2011, 9, 26-32.

8. Kizhedath, A.; Suneetha, V. Estimation of chlorophyll content in common household medicinal leaves and their utilization to avail health benefits of chlorophyll. J. Pharm. Res. 2011, 4, 1412-1413.

9. Balasundram, N.; Sundram, K.; Samman, S. Phenolic compounds in plants and agri-industrial by-products: Antioxidant activity, occurrence, and potential uses. Food Chem. 2006, 99, 191-203. [CrossRef]

10. Abdulmanea, K.; Prokudina, E.A.; Lanková, P.; Vaníčková, L.; Koblovská, R.; Zelený, V.; Lapčík, O. Immunochemical and HPLC identification of isoflavonoids in the Apiaceae family. Biochem. Syst. Ecol. 2012, 45, 237-243. [CrossRef]

11. Javed, H.; Khan, M.M.; Ahmad, A.; Vaibhav, K.; Ahmad, M.E.; Khan, A.; Ashafaq, M.; Islam, F.; Siddiqui, M.S.; Safhi, M.M.; et al. Rutin prevents cognitive impairments by ameliorating oxidative stress and neuroinflammation in rat model of sporadic dementia of Alzheimer type. Neuroscience 2012, 210, 340-352. [CrossRef] [PubMed]

12. Azuma, K.; Ippoushi, K.; Nakayama, M.; Ito, H. Absorption of chlorogenic acid and caffeic acid in rats after oral. J. Agric. Food Chem. 2000, 48, 5496-5500. [CrossRef]

13. Ong, K.W.; Hsu, A.; Kwong, B.; Tan, H. Anti-diabetic and anti-lipidemic effects of chlorogenic acid are mediated by ampk activation. Biochem. Pharmacol. 2013, 85, 1341-1351. [CrossRef] [PubMed]

14. Kozai, T.; Niu, G. Plant factory as a resource-efficient closed plant production system. In Plant Factory: An indoor Vertical Farming System for Efficient Quality Food Production; Kozai, T., Niu, G., Takagaki, M., Eds.; Academic Press: San Diego, CA, USA, 2016; pp. 69-90.

15. Sakamoto, M.; Suzuki, T. Effect of root-zone temperature on growth and quality of hydroponically grown red leaf lettuce (Lactuca sativa L. cv. Red Wave). Am. J. Plant Sci. 2015, 6, 2350-2360. [CrossRef]

16. He, J.; See, X.E.; Qin, L.; Choong, T.W. Effects of root-zone temperature on photosynthesis, productivity and nutritional quality of aeroponically grown salad rocket (Eruca sativa) vegetable. Am. J. Plant Sci. 2016, 7, 1993-2005. [CrossRef]

17. Yan, Q.; Duan, Z.; Mao, J.; Li, X.; Dong, F.; Yan, Q.; Duan, Z.; Mao, J.; Li, X.; Dong, F. Effects of root-zone temperature and $\mathrm{N}, \mathrm{P}$, and $\mathrm{K}$ supplies on nutrient uptake of cucumber (Cucumis sativus $\mathrm{L}$.) seedlings in hydroponics Effects of root-zone temperature and N, P, and K supplies on nutrient uptake of c. Soil Sci. Plant Nutr. 2012, 58, 707-717. [CrossRef]

18. Al-Rawahy, M.S.; Al-Rawahy, S.A.; Al-Mulla, Y.A.; Nadaf, S.K. Effect of cooling root-zone temperature on growth, yield and nutrient uptake in cucumber grown in hydroponic system during summer season in cooled greenhouse. J. Agric. Sci. 2019, 11, 47-60. [CrossRef]

19. Nguyen, D.T.P.; Lu, N.; Kagawa, N.; Takagaki, M. Optimization of photosynthetic photon flux density and root-zone temperature for enhancing secondary metabolite accumulation and production of coriander in plant factory. Agronomy 2019, 9, 224. [CrossRef]

20. Falah, M.A.F.; Wajima, T.; Yasutake, D.; Sago, Y.; Kitano, M. Responses of root uptake to high temperature of tomato plants (Lycopersicon esculentum Mill.) in soil-less culture. J. Agric. Technol. 2010, 6, 543-558.

21. Wellburn, A.R. The spectral determination of chlorophylls a and $b$, as well as total carotenoids, using various solvents with spectrophotometers of different resolution. J. Plant Physiol. 1994, 144, 307-313. [CrossRef]

22. Prior, R.L.; Wu, X.; Schaich, K. Standardized methods for the determination of antioxidant capacity and phenolics in foods and dietary supplements. J. Agric. Food Chem. 2005, 53, 4290-4302. [CrossRef] [PubMed]

23. Gonçalves, S.; Gomes, D.; Costa, P.; Romano, A. The phenolic content and antioxidant activity of infusions from Mediterranean medicinal plants. Ind. Crops Prod. 2013, 43, 465-471. [CrossRef] 
24. Bantis, F.; Ouzounis, T.; Radoglou, K. Artificial LED lighting enhances growth characteristics and total phenolic content of Ocimum basilicum, but variably affects transplant success. Sci. Hortic. (Amst.) 2016, 198, 277-283. [CrossRef]

25. Kagawa, N.; Iguchi, H.; Henzan, M.; Hanaoka, M. Drying the leaves of Perilla frutescens increases their content of anticancer nutraceuticals. Food Sci. Nutr. 2019, 7, 1494-1501. [CrossRef] [PubMed]

26. Cooper, A.J. Root temperature and plant growth: A review. In Research review 4, Commonwealth Bureau of Horticulture and Plantation Crops; Commonwealth Agriculture Bureaux: East Malling, Kent, UK, 1973; pp. 59-72.

27. Nxawe, S.; Ndakidemi, P.A.; Laubscher, C.P. Possible effects of regulating hydroponic water temperature on plant growth, accumulation of nutrients and other metabolites. Afr. J. Biotechnol. 2010, 9, 9128-9134.

28. Chadirin, Y.; Hidaka, K.; Takahashi, T.; Sago, Y.; Wajima, T.; Kitano, M. Application of temperature stress to roots of spinach I. Effect of the low temperature stress on quality. Environ. Control Biol. 2011, 49, 133-139. [CrossRef]

29. Chadirin, Y.; Sago, Y.; Hidaka, K.; Wajima, T.; Kitano, M. Application of temperature stress to root zone of spinach III. Effective method for short term application of low and high temperature stresses to toots. Environ. Control Biol. 2012, 50, 199-207. [CrossRef]

30. Ogawa, E.; Hikosaka, S.; Goto, E. Effects of nutrient solution temperature on the concentration of major bioactive compounds in red perilla. J. Agric. Meteorol. 2018, 74, 71-78. [CrossRef]

31. Trejo-Téllez, I.L.; Fernando, G.-M.C. Nutrient Solutions for Hydroponic Systems. In Hydroponics-A Standard Methodology for Plant Biological Researches; Asao, T., Ed.; IntTechOpen: Rijeka, Croatia, 2012; pp. 1-22.

32. Morard, P.; Silvestre, J. Plant injury due to oxygen deficiency in the root environment of soilless culture: A review. Plant Soil 1996, 184, 243-254. [CrossRef]

33. Sakamoto, M.; Uenishi, M.; Miyamoto, K.; Suzuki, T. Effect of root-zone temperature on the growth and fruit quality of hydroponically grown strawberry plants. J. Agric. Sci. 2016, 8, 122-131.

34. Costa, L.D.; Tomasi, N.; Gottardi, S.; Iacuzzo, F.; Cortella, G.; Manzocco, L.; Pinton, R.; Mimmo, T.; Cesco, S. The effect of growth medium temperature on corn salad [Valerianella locusta (L.) laterr] baby leaf yield and quality. HortScience 2011, 46, 1619-1625. [CrossRef]

35. Islam, M.Z.; Lee, T.Y.; Mele, M.A.; Choi, L.I.; Kang, M.H. The effect of phosphorus and root zone temperature on anthocyanin of red romaine lettuce. Agronomy 2019, 9, 47. [CrossRef]

36. Kefeli, A.I.; Kalevitch, M.V.; Borsari, B. Phenolic cycle in plants and environment. J. Cell Molercular Biol. 2003, 2, 13-18.

37. Haldimann, P.; Feller, U.R.S. Growth at moderately elevated temperature alters the physiological response of the photosynthetic apparatus to heat stress in pea (Pisum sativum L.) leaves. Plant Cell Environ. 2005, 28, 302-317. [CrossRef]

38. Blokhina, O.; Virolainen, E.; Fagerstedt, K.V. Antioxidants, oxidative damage and oxygen deprivation stress: A review. Ann. Bot. 2003, 91, 179-194. [CrossRef]

39. Pham, A.T.; Kwon, D.Y.; Lee, S.; Arasu, M.V. Enhancement of chlorogenic acid production in hairy roots of Platycodon grandiflorum by over-expression of an Arabidopsis thaliana transcription factor AtPAP1. Int. J. Mol. Sci. 2014, 15, 14743-14752.

(C) 2020 by the authors. Licensee MDPI, Basel, Switzerland. This article is an open access article distributed under the terms and conditions of the Creative Commons Attribution (CC BY) license (http://creativecommons.org/licenses/by/4.0/). 